\title{
Establishment of porcine nuclear transfer-derived embryonic stem cells using induced pluripotent stem cells as donor nuclei
}

\author{
Seiki HARAGUCHI'), Thanh Quang DANG-NGUYEN ${ }^{2}$, David WELLS'), \\ Daiichiro FUCHIMOTO ${ }^{1)}$, Tomokazu FUKUDA ${ }^{4)}$ and Tomoyuki TOKUNAGA ${ }^{1)}$ \\ 1) Animal Biotechnology Unit, Institute of Agrobiological Sciences, NARO, Ibaraki 305-0901, Japan \\ 2) Reproductive Biology Unit, Institute of Agrobiological Sciences, NARO, Ibaraki 305-0901, Japan \\ 3) AgResearch, Ruakura Research Centre, Hamilton, New Zealand \\ 4) Laboratory of Cell Engineering and Molecular Genetics, Iwate University, Iwate 020-8550, Japan
}

\begin{abstract}
We investigated whether sequential reprogramming via porcine induced pluripotent stem cells (piPSCs) or exposure to oocyte cytoplasm following nuclear transfer could generate nuclear transfer-derived ESCs (piPSCs-ntESCs). Nuclear transfer embryos were reconstructed with piPSCs possessing a ZsGreen fluorescent marker for expression of exogenous Nanog and Lin28. Reconstructed oocytes developed to morphologically normal 8-cell/morulae (35/93, 37.6\%) and blastocysts $(12 / 93,12.9 \%)$. Although most green fluorescent protein-positive blastocysts showed efficient outgrowth $(8 / 10,80 \%)$, none formed primary colonies and all cultures degenerated. Conversely, $15 \%$ of fluorescent positive 8-cell/ morula stage embryos showed outgrowth (6/40), with three forming primary colonies (7.5\%). All three were expanded and maintained as piPSC-ntESC lines. These cell lines expressed stem cell marker genes and proteins. Despite inactivation of one $\mathrm{X}$ chromosome, all piPSC-ntESC lines formed teratomas comprising derivatives from all three embryonic germ layers. Strong SSEA1, 3, and 4 expression was detected at the 8-cell/morula stage in embryos reconstructed from both piPSCs and porcine embryonic fibroblasts (PEFs). SSEA3 was notably absent from IVF controls at pre-implantation embryo stages. Finally, we attempted to establish ntESCs from 8-cell/morulae reconstructed with PEFs using the same culture conditions as those for piPSC-ntESC derivation. Although eight primary colonies arose from 107 embryos (7.5\%), they all degenerated after the first passage culture. Early and sustained expression of key reprogramming regulatory factors may be critical for pluripotent stem cell derivation to derive piPSC-ntESCs from 8-cell/morula stages, while the expression of SSEAs may be involved in the initial stem cell colony formation phases.
\end{abstract}

Key words: Embryonic stem (ES) cells, Induced pluripotent stem (iPS) cells, Nuclear transfer-derived embryonic stem cells (ntESCs), Porcine, Reconstructed embryos

(J. Reprod. Dev. 66: 163-174, 2020)

$\mathbf{M}$ any studies have attempted to establish porcine pluripotent stem cells like embryonic stem cells (ESCs) and induced pluripotent stem cells (iPSCs). The defining features of authentic pluripotent cells are unlimited potential for self-renewal and the ability to differentiate into derivatives of all embryonic lineages in chimeras. Critically, naïve pluripotent stem cells capable of contributing to the germline have only been demonstrated in rats $[1,2]$ and mice $[3,4]$. In contrast, more developmentally advanced, primed pluripotent stem cells cannot give rise to germline chimaeras [5-7]. The inhibition of critical molecular pathways that predispose cellular differentiation and specific supplementary factors are essential to maintain the pluripotent ground state. Recently, this pathway-inhibition paradigm has been further extended to define a specific combination of small molecule inhibitors and factors that result in the establishment of cultured cell

Received: October 25, 2019

Accepted: January 4, 2020

Advanced Epub: January 26, 2020

(C)2020 by the Society for Reproduction and Development

Correspondence: S Haraguchi (e-mail: sharaguchi@affrc.go.jp)

This is an open-access article distributed under the terms of the Creative Commons Attribution Non-Commercial No Derivatives (by-nc-nd) License. (CC-BY-NC-ND 4.0: https://creativecommons.org/licenses/by-nc-nd/4.0/) lines with undifferentiated blastomere-like molecular features and developmental potential, which are called expanded potential stem cells (EPSCs) $[8,9]$. EPSCs are uniquely able to contribute to both embryonic and extra-embryonic lineages in mouse, human, and pig.

The domestic pig is recognized as one of the most suitable animal models for human diseases, cell therapy, and transplantation medicine because of its genetic, anatomical, and physiological similarities with humans. Pigs can now provide safer organ and tissue resources for xenotransplantation because endogenous retrovirus-free pigs have been produced using genome editing and nuclear transfer technology [10]. Similarly, porcine stem cell research also has great potential as an experimental tool for regenerative medicine and developing novel therapeutic treatments before clinical testing. Therefore, pluripotent cell lines are highly desirable for their in vitro self-renewal ability and in vivo developmental potential. They are also more amenable to genetic modification than primary somatic cells.

We previously established inner cell mass (ICM)-derived porcine ESC-like cells (pESLCs) from conventional in vitro fertilized (IVF) blastocysts by combining GSK3 (CHIR99021), MEK (PD184352), and ROCK (Y-27632) inhibitors with LIF supplementation [11]. These embryo-derived cell lines show extensive self-renewal capacity. However, the female cells possess one inactivated X-chromosome 
(XaXi), indicative of a primed pluripotent state, although in vivo pluripotency was not examined. Subsequently, Fukuda et al. [12] created porcine-iPSCs (piPSCs) using two separate lentiviral vectors to deliver the six mouse reprogramming factor genes Oct $3 / 4$, Klf4, Sox2, c-Myc, Lin28, and Nanog combined with GSK (CHIR99021), MEK (PD0325901), PKC (GFX109203), and ROCK (thiazovivin) inhibitors. The resulting piPSCs possess sufficient self-renewal and pluripotent capacity, and can also form teratomas in vivo and incorporate into chimeric embryos in vitro [12]. Importantly, the female piPSC lines have two active $\mathrm{X}$ chromosomes (XaXa), suggesting a naïve-like pluripotent state. These piPSCs also integrated a ZsGreen reporter, which is bicistronically co-expressed with Lin 28 and Nanog genes from the lentiviral vector. However, the emission of the green fluorescence disappeared once the cells shifted toward a differentiated state. Therefore, we hypothesized that the efficient derivation of piPSC nuclear transfer-derived ESCs (piPSCs-ntESCs) could be possible while monitoring the fluorescence marker.

It has been reported that nuclear transfer-derived ESC clones have a higher rate of developmental competence compared to somatic cell-derived clones $[13,14]$, implying that ESCs might require less epigenetic reprogramming than somatic cells. Conversely, although continuous expression of exogenous reprogramming factors is necessary to maintain piPSC pluripotency, it is not known how such unphysiological conditions with integrated reprogramming expression vectors affect reconstructed oocyte development and subsequent porcine ntESC derivation.

Here, we attempted to establish piPSC-ntESCs to address whether oocytes reconstructed with piPSCs can develop to blastocysts. We also assessed whether the green fluorescent reporter linked to the exogenous mouse Lin 28 and Nanog expression in these donor cells is restricted to the pluripotent ICM. We also used the reconstructed embryos to examine whether ntESCs can be efficiently established while monitoring the fluorescent signal. Furthermore, we determined whether the piPSC-ntESCs inherit the molecular and developmental characteristics of the parental iPSC line. We anticipated that these outcomes would provide further understanding to help establish non-transgenic porcine pluripotent stem cells and contribute to various biomedical research applications in pigs.

\section{Materials and Methods}

All chemicals were purchased from Sigma-Aldrich unless otherwise indicated.

\section{Production of nuclear transfer embryos reconstructed with piPSC}

The piPSCs used in this study represented Clone 1 described by Fukuda et al. [12]. The piPSCs were dispersed to a single cell suspension by using Accutase (Nakalai tesque, Kyoto, Japan) and pooled in piPSC medium (see below) supplemented with $10 \mathrm{mM}$ HEPES. Porcine oocytes were matured in vitro as previously described [15], and nuclear transfer was performed according to Oback and Wells [16] with modifications for pig. Briefly, oocytes with a first polar body were selected using $0.2 \mathrm{M}$ sucrose treatment before enucleating in HEPES buffered Medium 199 supplemented with 20\% FCS using the "squeezing method" according to Akagi et al. [17].
Enucleated oocytes were treated with $0.5 \%$ pronase to remove the zona pellucida. Each resulting zona-free cytoplast was attached to a single piPSC possessing a smooth and clear membrane by incubating in $300 \mu \mathrm{g} / \mathrm{ml}$ phytohemagglutinin for $15 \mathrm{~min}$. The cytoplast-cell couplets were orientated between a pair of parallel electrodes $1 \mathrm{~mm}$ apart with alternating current infusion medium containing $0.28 \mathrm{M}$ mannitol, $0.01 \mathrm{mM} \mathrm{CaCl}_{2}, 0.1 \mathrm{mM} \mathrm{MgSO}_{4}, 0.5 \mathrm{mM} \mathrm{HEPES}$, and 0.1 $\mathrm{mg} / \mathrm{ml}$ bovine serum albumin (BSA). A single direct current (DC) pulse of $2 \mathrm{kV} / \mathrm{cm}$ was applied for $20 \mu \mathrm{sec}$ for cytoplast-cell fusion using an electro cell fusion generator (LF101; Nepa-Gene, Japan). Cytoplast-cell couplets were kept in HEPES buffered medium 199 supplemented with $20 \% \mathrm{FCS}$ and $5 \mu \mathrm{g} / \mathrm{ml}$ cytochalasin B for around $30 \mathrm{~min}$ before evaluating fusion. After approximately $2-3 \mathrm{~h}$, fused couplets were activated with a single DC pulse of $1.5 \mathrm{kV} / \mathrm{cm}$ for 100 $\mu$ sec using the electro cell fusion generator in medium containing

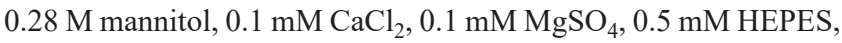
and $0.1 \mathrm{mg} / \mathrm{ml} \mathrm{BSA} \mathrm{before} \mathrm{incubating} \mathrm{in} \mathrm{PZM3} \mathrm{medium} \mathrm{(Research}$ Institute for the Functional Peptides, Yamagata, Japan) supplemented with $5 \mu \mathrm{g} / \mathrm{ml}$ cytochalasin B for $3 \mathrm{~h}$. Reconstructed oocytes were cultured individually in PZM3 in microwell dishes (DNP, Tokyo, Japan) before collecting.

\section{IVF}

IVF was conducted according to Kikuchi et al. [18]. The medium for IVF was a modified Pig-FM [19] containing $90 \mathrm{mM} \mathrm{NaCl}, 12$ $\mathrm{mM} \mathrm{KCl}, 25 \mathrm{mM} \mathrm{NaHCO}_{3}, 0.5 \mathrm{mM} \mathrm{NaH}_{2} \mathrm{PO}_{4}, 0.5 \mathrm{mM} \mathrm{MgSO}_{4}, 10$ $\mathrm{mM}$ sodium lactate, $10 \mathrm{mM}$ HEPES, $8 \mathrm{mM} \mathrm{CaCl}_{2}, 2 \mathrm{mM}$ sodium pyruvate, $2 \mathrm{mM}$ caffeine, and $5 \mathrm{mg} / \mathrm{ml}$ BSA. Groups of 15-20 oocytes were transferred into $100 \mu \mathrm{IVF}$ droplets covered with paraffin oil. Frozen-thawed epididymal spermatozoa were pre-incubated in Medium 199 (with Earle's salts and HEPES, pH adjusted to 7.8) for $15 \mathrm{~min}$. The sperms were diluted to a final concentration of $1 \times$ $10^{5} \mathrm{sperm} / \mathrm{ml}$ in the IVF medium droplet with oocytes. Sperm and oocytes were co-incubated for $30 \mathrm{~min}$ at $38.5^{\circ} \mathrm{C}$ in $5 \% \mathrm{CO}_{2}, 5 \% \mathrm{O}_{2}$, and $90 \% \mathrm{~N}_{2}$. The oocytes and bound sperm were transferred into fresh IVF droplets for another $2.5 \mathrm{~h}$ under the same incubation conditions.

\section{Establishment and culture of piPSC-ntESCs}

A flow chart of the experimental protocol is shown in Fig. 1A. Media: Porcine ESC medium [11] and iPSC medium [12] used here followed previous studies with slight modifications. ESC medium contained KnockOut-DMEM supplemented with $2 \mathrm{mM}$ GlutaMAX, 1\% MEM non-essential amino acids, 1\% antibioticantimycotic solution, 15\% FCS (SH30070, Hyclone) (all from Thermo Fisher Scientific, Waltham, MA, USA), 1\% porcine recombinant LIF (pLIF) [20], $0.1 \mathrm{mM} \beta$-mercaptoethanol, $5 \mathrm{ng} / \mathrm{ml}$ basic FGF (Human Recombinant; BD Biosciences, San Jose, CA, USA), and 2\% polyvinylpyrrolidone (MW: 360,000). iPSC medium contained KnockOut-DMEM supplemented with 2 mM GlutaMAX, 1\% MEM non-essential amino acids solution, $1 \%$ antibiotic-antimycotic solution, 15\% KnockOut-Serum Replacement (KSR; Thermo Fisher Scientific), 1\% pLIF, 0.1 mM $\beta$-mercaptoethanol, $0.25 \mu$ M PD0325901 (Cayman Chemical, Ann Arbor, MI, USA), $0.75 \mu \mathrm{M}$ CHIR99021 (Axon Medchem, Groningen, The Netherlands), $0.25 \mu \mathrm{M}$ thiazovivin (Stemgent, Cambridge, MA, USA), and $3 \mu \mathrm{M} \mathrm{GF-109203x}$ (Focus Biomolecules, Plymouth Meeting, PA, USA). 
A

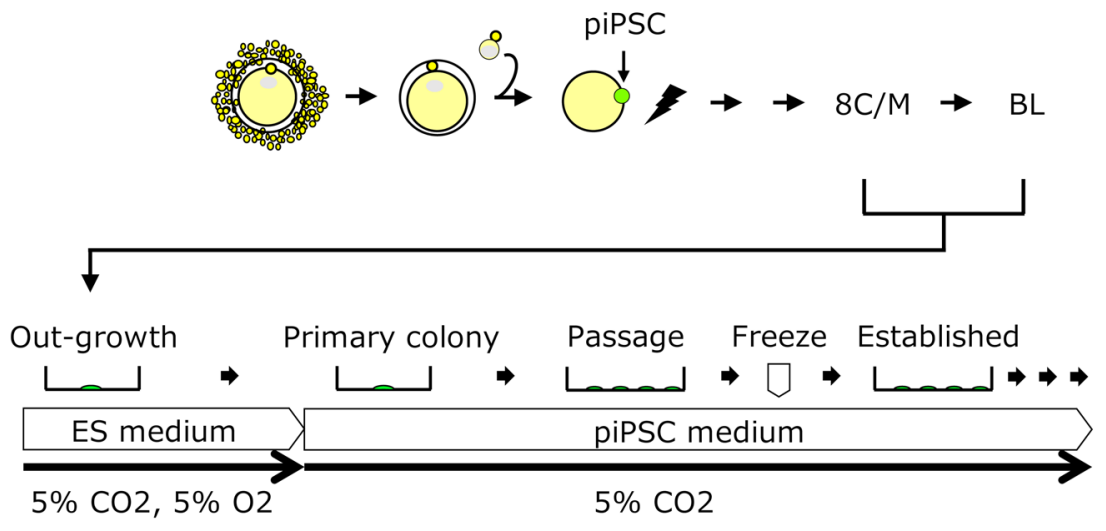

B

Morphologically normal development of reconstructed oocytes.

\begin{tabular}{ccc}
\hline $\begin{array}{c}\text { No. of } \\
\text { oocytes }\end{array}$ & $\begin{array}{c}\text { 8-cell/morula* } \\
(\%)\end{array}$ & $\begin{array}{c}\text { Blastocysts** } \\
(\%)\end{array}$ \\
\hline 93 & $35(37.6)$ & $12(12.9)$ \\
\hline
\end{tabular}

*,** Fluorescence positive was 32 and 10 , respectively.

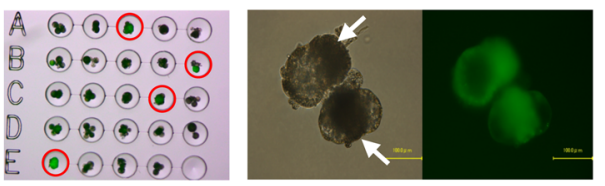

C

\begin{tabular}{ccc}
\multicolumn{3}{c}{ Out-growth but no primary colony from blastocysts. } \\
$\begin{array}{c}\text { No. of } \\
\text { fluoro-Blastocysts }\end{array}$ & $\begin{array}{c}\text { Out-growth } \\
(\%)\end{array}$ & $\begin{array}{c}\text { Primary colony } \\
(\%)\end{array}$ \\
\hline 10 & $8(80)$ & $0(0)$ \\
\hline
\end{tabular}

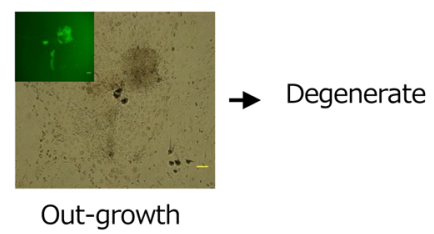

D

\begin{tabular}{ccc}
\hline $\begin{array}{c}\text { Out-growth and primary colonies from 8-cell/morula. } \\
\text { No. of } \\
\text { fluoro-8-cell/morula }\end{array}$ & $\begin{array}{c}\text { Out-growth } \\
(\%)\end{array}$ & $\begin{array}{c}\text { Primary colony } \\
(\%)\end{array}$ \\
\hline 40 & $6(15)$ & $3(7.5)$ \\
\hline
\end{tabular}

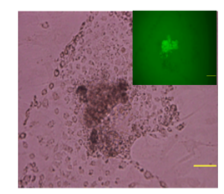

Out-growth

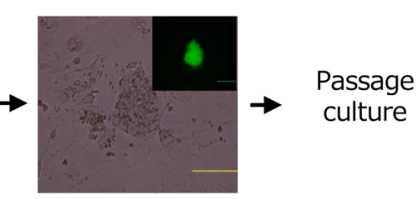

Primary colony

Fig. 1. Establishment of pluripotent stem cell (piPSC)-nuclear transfer-derived ESC (ntESC) lines. (A) A flow chart for porcine reconstructed oocyte production with piPSC donors and ntESC line derivation. Reconstructed oocytes were generated using single cytoplast nuclear transfer. (B) Porcine oocytes reconstructed with piPSCs develop into morphologically normal blastocysts. Embryos were individually cultured in microwells. Red circles show the 8-cell/morula (8C/M) embryos expressing ZsGreen fluorescence. Fluorescence was observed in both trophoblast and inner cell mass (ICM) of blastocysts. Arrows indicate ICM. Note that the blastocysts collapsed while taking photographs. (C) ZsGreen fluorescent positive blastocysts attached to feeder cells and began to out-grow. Although fluorescent positive cell clumps were observed (inset), none formed a primary colony, and all finally degenerated after passage culture. (D) Three piPSC-ntESC lines were successfully generated from $8 \mathrm{C} / \mathrm{M}$ embryos. ZsGreen fluorescent positive signals were confirmed in outgrowth cell clumps from six original embryos and three resulting primary colonies. None were observed in differentiated cells (insets). Scale bars: $100 \mu \mathrm{m}$.

Outgrowth culture: Reconstructed oocytes that developed either to 8 -cell/morula $(8 \mathrm{C} / \mathrm{M})$ stage embryos on Day 4 or blastocysts on Day 5 and expressed the ZsGreen fluorescence marker were transferred to a 4-well dish containing mitomycin $\mathrm{C}$ treated mouse embryonic fibroblast (MEF) feeder cells. Embryos were cultured in $500 \mu \mathrm{l}$ of ESC medium under a humidified atmosphere of $5 \% \mathrm{CO}_{2}, 5 \% \mathrm{O}_{2}$, and $90 \% \mathrm{~N}_{2}$ at $38^{\circ} \mathrm{C}$ for 2 days. The medium was changed to iPSC medium and replaced every second day. Green fluorescent positive 
primary colonies were mechanically broken up into small pieces using a glass capillary fitted with a mouthpiece before transferring onto new feeder layers in iPSC medium. After seeding, the colonies were allowed to grow to a larger size ( $>300 \mu \mathrm{m}$ diameter) before they were repeatedly split into small pieces using a glass capillary.

Passage culture: Multiple colonies from each embryo were propagated in single wells of 4-well dishes before eventually dissociating with Accutase into a single cell suspension and passaging onto two new wells with fresh feeder layers (passage 1: P1). Cultures were subsequently expanded into 35-mm cell culture dishes (P2). All cultures were under a humidified atmosphere of $5 \% \mathrm{CO}_{2}$ in air at $38^{\circ} \mathrm{C}$. Cellbanker 1 cryopreservation media (Nippon Zenyaku Kogyo, Fukushima, Japan) was used for cryo-storage, and frozen cells were stored at either $-95^{\circ} \mathrm{C}$ or in liquid nitrogen. After thawing, the cells were plated onto a fresh feeder layer in iPSC medium. The medium was changed daily, and the cells were routinely passaged every 2-3 days at a ratio of $1: 2$ or $1: 3$.

\section{Alkaline phosphatase (AP) staining, chromosomal number analysis, and cell growth assay}

AP staining and chromosomal number analysis were carried out according to our previous report [11]. $8.0 \times 10^{5}$ cells $(\mathrm{P} 15-20)$ were plated in a $35-\mathrm{mm}$ cell culture dish (set to $\mathrm{P} 0$ ) for the cell growth assay. The medium was changed every day, and the cells were passaged every two days after counting the cell number. The cells were passaged at a ratio of 1:2 or 1:3 depending on the cell density, and they were maintained for six days (P3).

\section{Semi-quantitative reverse transcription (RT)-PCR}

Total RNA was prepared using the RNeasy Mini Kit (QIAGEN, Hilden, Germany) combined with DNase I treatment. First strand cDNA was synthesized using a PrimeScript II 1st strand cDNA Synthesis Kit (Takara Bio, Shiga, Japan), and PCR was performed with EmeraldAmp PCR Master Mix (Takara Bio). PCR conditions were as follows: $98^{\circ} \mathrm{C}$ for $10 \mathrm{sec}, 60^{\circ} \mathrm{C}$ for $30 \mathrm{sec}$, and $72^{\circ} \mathrm{C}$ for $30 \mathrm{sec}$. PCR amplification of $G A P D H$ was initially performed to equalize the cDNA amount. After equalization, PCR for the genes of interest was performed on the first strand cDNA for 30-40 cycles. The PCR primers used are listed in our previous report [11]. Some of the key marker genes as described in human ESCs were examined to analyze naïve and primed marker gene expression [21, 22]. Accession numbers, primer sequences, and expected product sizes are as follows. Naïve marker genes: FAM151A (XM_021096591.1, F: 5'- aatgttggccttcaggaacctgcagc-3' and R: 5'-atgtctgtgaccagctgttccetgtag-3', 383 bp), TFCP2L1 (XM_005671641.3, F: 5'-gtaacctgctccgtgaccgtgaccat-3' and R: 5'- taggtggecetgagtgtccaccacacc-3', $261 \mathrm{bp}$ ), and GATA6 (NM_214328.2, F: 5'ttgaacgggacgtaccatcaccatc-3' and R: 5'-acagttggcacaggacaatccaagc-3', 378 bp). Primed marker genes: THY1 (NM_001146129.1, 5'-attggcatcgctctcttgctaacag-3' and R: 5'-acacagagatattettgctggagatgc-3', 355 bp), NEFM (XM_005670439.3, F: 5'-tagagaaggtcacttcccatgccatc- $3^{\prime}$ and R: 5'-actgtgcatgtcaacgaggttctcc-3', 470 bp), and XIST (KC753465.1, F: 5'-agccacattatgggtgtcttgttctag-3' and R: 5'-ttggaaagacettgggtaccacccac-3', 502 bp). PCR was performed for $35 \mathrm{cycles}$ at $98^{\circ} \mathrm{C}$ for $10 \mathrm{sec}$ and $68^{\circ} \mathrm{C}$ for $60 \mathrm{sec}$.

\section{Combined bisulfite restriction analysis (COBRA)}

COBRA was performed as previously described to examine the methylation status of the XIST differentially methylated region (DMR) [11]. The restriction enzyme cleaves the PCR fragments only if it was originally methylated because of bisulfite treatment-induced changes in the DNA sequence. The PCR products were digested with $B s t \mathrm{UI}, T a q \mathrm{I}$, and $A c i$ I restriction enzymes and separated using $2 \%$ agarose gel electrophoresis.

\section{Immunocytochemistry}

Cells were fixed with $4 \%$ paraformaldehyde in PBS for $15 \mathrm{~min}$. For the intracellular pluripotency markers, the samples were blocked and permeabilized with $0.25 \%$ Triton X-100 and $2 \%$ BSA in PBS (wash buffer) for $30 \mathrm{~min}$. The samples were blocked with $2 \%$ BSA in PBS (wash buffer) for SSEA immunocytochemistry. The cells were incubated with the appropriate primary antibodies diluted in the wash buffer at $4{ }^{\circ} \mathrm{C}$ overnight before washing and incubating with the secondary antibodies for $1 \mathrm{~h}$ at room temperature. Nuclei were counterstained with $2 \mu \mathrm{g} / \mathrm{ml}$ DAPI. The specimens were imaged using a fluorescent microscopy system (BZ-X700; KEYENCE, Osaka, Japan) or Zeiss LSM780 confocal microscope. The primary antibodies used were anti-SSEA-1 (1:100, ab16285, abcam, Cambridge, UK), anti-SSEA-3 (1:20, \#10431, Immuno-Biological Laboratories, Gunma, Japan), anti-SSEA-4 (1:100, \#09-0006, Stemgent), rabbit anti-Oct-4A (1:200, \#2840, Cell Signaling Technology (CST), Danvers, MA, USA), rabbit anti-Sox2 (1:200, \#3579, CST), rabbit anti-c-Myc (1:400, \#5605, CST), rabbit anti-LIN28A (1:200,\#3695, CST), rabbit anti-KLF4 (1:200,\#4038, CST), and rabbit anti-Nanog (1:100, ab109250, abcam). The secondary antibodies were Alexa Fluor 594 goat anti-rabbit IgG (1:400, A-11072, Thermo Fisher Scientific) or goat anti-mouse IgM mu chain (1:400, ab97009, abcam).

\section{Western blotting}

Cells were detached from the feeder cells, counted, and adjusted such that each sample contained an equal number of cells. Western blotting was performed as previously described [11]. The membranes were probed with anti-Oct-4A $(1: 1,000, \# 2840$, CST), anti-Sox2 $(1: 1,000, \# 3579$, CST), anti-KLF4 (1:1,000, \#4038, CST), antiLIN28A (1:1,000,\#3695, CST), anti-Nanog (1:1,000,\#4903, CST), or anti- $\alpha$-Tubulin $(1: 2,000, \# 2125$, CST $)$ antibodies with 5\% Blocking One (Nacalai Tesque) in TBST overnight at $4^{\circ} \mathrm{C}$. After washing with TBST, the membranes were incubated with anti-rabbit IgG $(1: 2,000, \# 7074, \mathrm{CST})$ in 5\% Blocking One in TBST for $1 \mathrm{~h}$ at room temperature. The membranes were washed with TBST and processed using Chemi-Lumi One Ultra (Nacalai Tesque). Immunoblots were visualized using the ImageQuant LAS 500 (GE Healthcare, Chicago, IL, USA).

\section{Teratoma formation}

The cultured cells were treated with Accutase, and feeder cells were removed by using a cell strainer ( $35 \mu \mathrm{m}$; Falcon, Corning, NY, USA). Approximately $1 \times 10^{6}$ cells were resuspended in iPSC medium without inhibitors or pLIF. The medium was carefully removed after centrifuging. The cell pellet was xenografted into the testis of SCID mice using a fine glass capillary with a mouthpiece. Three to five mice per clone were used, and teratoma formation was examined 
12 weeks later. Mice were maintained and used in accordance with guidelines issued by the NARO Institutional Animal Care and Use Committee. Teratomas were excised and fixed in Mildform 10NM (FUJIFILM Wako Pure Chemical, Osaka, Japan). A small piece of each teratoma was embedded in paraffin, sectioned, stained using hematoxylin and eosin (HE), and examined using a microscope [23].

\section{Results}

Reconstructed porcine oocytes with piPSCs can develop to blastocysts

We initially examined the developmental competence of embryos reconstructed with piPSCs. The reconstructed oocytes developed to blastocysts with apparently normal morphology. Out of 93 reconstructed embryos produced in three replicates, $35(37.6 \%)$ $8 \mathrm{C} / \mathrm{M}$ embryos and 12 (12.9\%) blastocysts were produced on Days 4 and 5, respectively (Fig. 1B). Not all embryos showed ZsGreen fluorescence, but we confirmed that fluorescence was observed from the late 4-cell stage onward (data not shown). The proportions of fluorescent positive embryos were $32 / 35$ and $10 / 12$, respectively. The ZsGreen signal was observed in all blastocysts including the ICM and trophoblast (Fig. 1B).

\section{Establishment of piPSC-ntESC lines}

The ZsGreen fluorescent positive blastocysts were transferred onto feeder cells on Day 5. Eight blastocysts $(8 / 10,80 \%)$ attached to the feeder layers and began to outgrow, expressing green fluorescence in the small ICM clump (Fig. 1C). Each clump was carefully transferred to new feeder cells and cultured. However, no primary colonies appeared and the cells finally degenerated. We examined piPSC-ntESC derivation from the $8 \mathrm{C} / \mathrm{M}$ embryos on Day 4 . Although the outgrowth rate was lower than in blastocysts $(6 / 40,15 \%$ vs. $8 / 10,80 \%)$, three primary colonies $(3 / 40,7.5 \%)$ appeared (Fig. 1D). They were subjected to repeated passage culture to expand the cell numbers. After freezethawing, the three candidates all maintained their growth ability and morphology. The established cell lines did not show cell death even after enzymatic digestion of colonies to single cell suspensions. We successfully established three piPSC-ntESC lines: $\mathrm{Cl1}, \mathrm{Cl} 2$, and $\mathrm{Cl} 3$. The colony morphologies were compacted and smooth-edged with a shiny border appearance like the parental iPSCs (Fig. 2A upper panel). The cultures had strong AP activity (Fig. 2A middle panel) and showed ZsGreen fluorescence (Fig. 2A lower panel). Both green fluorescence positive and negative cells were initially observed in the Cl1 line. However, the fluorescence was finally silenced after 15 Cl1 culture passages (see below). Despite this, the C11 line still maintained the typical stem cell morphology and growth ability. To date, $\mathrm{Cl1}, \mathrm{Cl} 2$, and $\mathrm{Cl} 3$ have been continuously maintained for over 40 passages without any overt change in morphology.

We realized that the cell size differed between the three piPSCntESC lines while undergoing routine passage culture. The established lines increased in cell size compared to the piPSC cell diameter $(12.14 \pm 2.07 \mu \mathrm{m}): \mathrm{Cl} 2(12.61 \pm 1.51 \mu \mathrm{m}), \mathrm{Cl} 1(16.22 \pm 3.86 \mu \mathrm{m})$, and $\mathrm{Cl} 3(20.39 \pm 3.99 \mu \mathrm{m})(\mathrm{n}=30$ in each cell line) (Fig. 2B). Interestingly, the cell proliferation rate of each clone was inverse correlated with the cell size; lines with smaller cells grew at a faster rate. The parental piPSCs had the fastest proliferation rate followed by $\mathrm{Cl} 2, \mathrm{Cl1}$, and $\mathrm{Cl3}$ in order of cell size (Fig. 2C).

The chromosome number of each cell line is shown in Table 1. The percentage of cells possessing a normal diploid chromosomal number $(2 \mathrm{n}=38)$ when examined between passages $15-20$ for $\mathrm{Cl1}$, $\mathrm{Cl} 2$, and $\mathrm{Cl} 3$ lines was $88.0 \%, 81.2 \%$, and $48.8 \%$, respectively. A high frequency of tetraploidy $(2 \mathrm{n}=76)$ was observed in $\mathrm{Cl} 3$.

\section{Semi-quantitative RT-PCR and COBRA analysis}

We comprehensively examined the endogenous porcine mRNA expression of undifferentiated markers OCT3/4, NANOG, SOX2, c-MYC, LIN28, KLF4, MEG3, DNMT, PECAM1, DPPA5, CDH1, and STAT3 according to our previous report [11]. The expression of all genes was observed in each clone (Fig. 3A). Although the strength of the expression patterns differed between the cell lines, there was a tendency for higher gene expression levels in $\mathrm{Cl} 2$ and lower levels in $\mathrm{Cl} 3$. The expression level of these genes was not necessarily the highest in the parental cell line. In fact, the expression of $O C T 3 / 4, M E G 3$, and DPPA5 in established piPSC-ntESC lines was higher than in the piPSCs. We next examined the expression/ suppression status of the six vector-derived mouse reprogramming factor genes (Fig. 3B right panel). Expression of Oct3/4 and Nanog was downregulated in iPSC-ntESC lines compared to piPSCs (Fig. 3B left panel). Among the cell lines, the expression of the mouse Oct3/4 in $\mathrm{Cl} 2$ and the mouse Nanog expression in $\mathrm{Cl} 3$ was higher than other clones. Mouse Nanog expression in $\mathrm{Cl1}$ was not detected up to passage number 45 , consistent with the disappearance of ZsGreen fluorescence (Fig. 4A).

COBRA analysis was performed for the XIST DMR to determine the $\mathrm{X}$ chromosome activation status in the female piPSC and piPSCntESC lines. The control samples confirmed the expected results: $\mathrm{XaY}$ in male, $\mathrm{XaXi}$ in female porcine embryonic fibroblast (PEFs), and XaXa in the female piPSCs [12]. Approximately half of the $\mathrm{PCR}$ products were digested with the restriction endonucleases in all piPSC-ntESC lines consistent with the results from the female PEFs. This indicated the presence of both active and inactive $\mathrm{X}$ chromosomes (XaXi status) (Fig. 3C). We further examined the expression of marker genes for naïve and primed states. Higher expression levels of the naïve marker genes FAM151A, TFCP2L1, and GATA6 were observed in piPSCs compared to piPSC-ntESC lines (Fig. 3D left panel). Conversely, the expression of the primed marker genes NEFM, THY1, and XIST was relatively higher in iPSC-ntESC lines than in piPSCs (Fig. 3D right panel). The expression status of XIST was in agreement with the COBRA analysis results. These results suggest that the piPSC-ntESC lines are in a primed pluripotent state.

Expression of cell surface and undifferentiated marker proteins

We examined the expression of the cell surface markers SSEA1, SSEA3, and SSEA4 in the established cell lines. Both SSEA3 and SSEA4 were strongly expressed in $\mathrm{Cl} 1, \mathrm{Cl} 2, \mathrm{Cl} 3$, and in piPSCs, which is consistent with the previous report by Fukuda et al. [12] (Fig. 4A). A faint SSEA1 signal was observed in $\mathrm{Cl1}$ and $\mathrm{Cl} 3$ using the same fluorescent microscope system (data not shown). A confocal microscope was utilized to examine the signal in more detail. As a result, the SSEA1 signal was confirmed in the $\mathrm{Cl1}$ and $\mathrm{Cl} 3$ lines and absent from both $\mathrm{Cl} 2$ and the parental piPSCs (Fig. 4A). In addition, the fluorescent signal from the ZsGreen gene in the $\mathrm{Cl1}$ cells (>P15) 
A
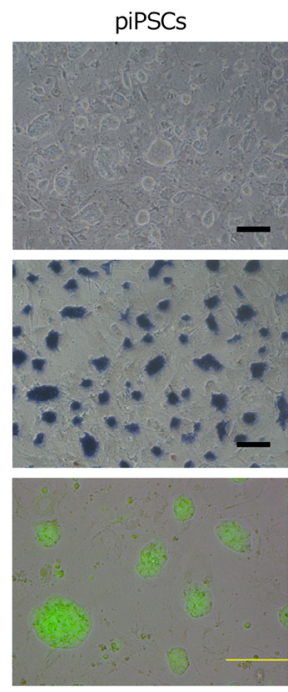

B

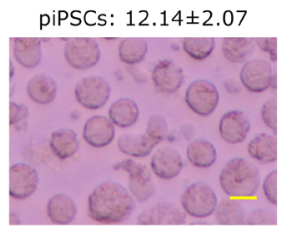

$\mathrm{Cl} 1$
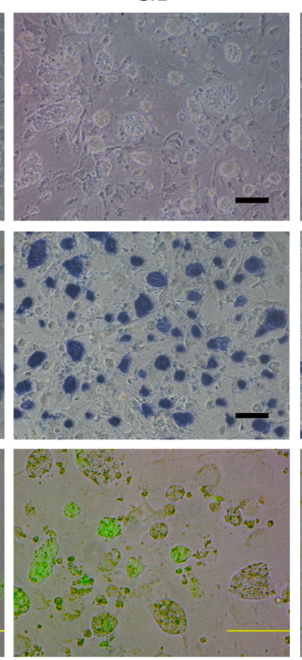

$\mathrm{Cl} 2: 12.61 \pm 1.51$

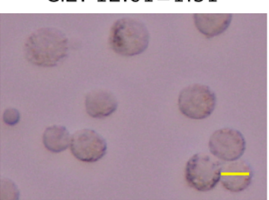

$\mathrm{Cl} 2$
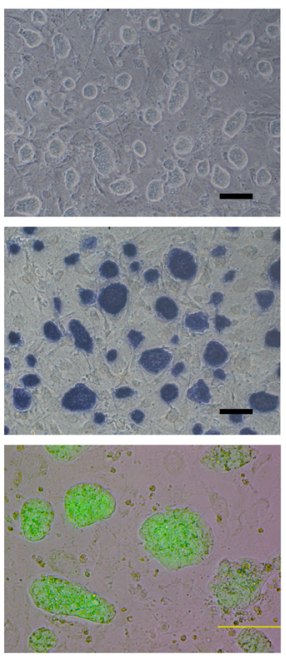

$\mathrm{Cl} 1: 16.22 \pm 3.86$

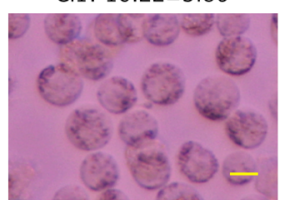

$\mathrm{Cl3}$
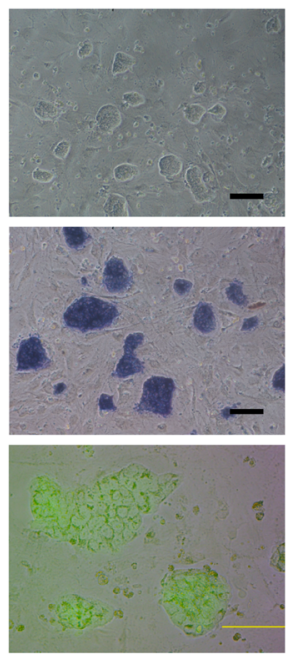

CI3: $20.39 \pm 3.99$

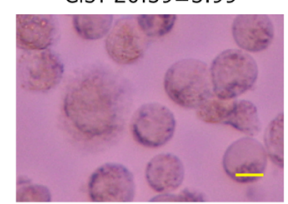

C

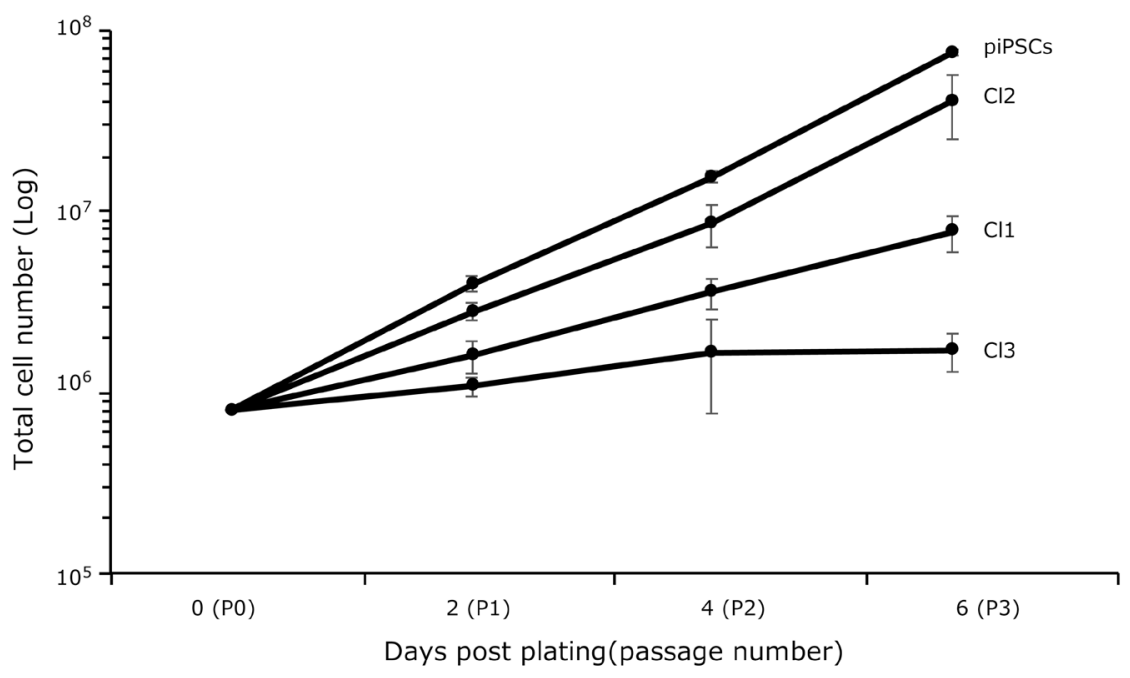

Fig. 2. Features of the established pluripotent stem cell (piPSC)-nuclear transfer-drived ESC (ntESC) lines, Cl1, $\mathrm{Cl} 2$, and $\mathrm{Cl} 3$ compared to the donor piPSCs. (A) All cell lines show smooth-edged colonies with shiny border appearance (upper panels) and strong alkaline phosphatase (AP) activity (middle panels). ZsGreen fluorescence was also observed in the colonies (lower panels). In Cl1, both ZsGreen positive and negative cell colonies were observed with the fluorescence signal finally disappearing after approximately 15 passages (see also Fig. 4A). Scale bars: $100 \mu \mathrm{m}$. (B) Cell size varies among cell lines. In ascending order: piPSCs, Cl2, Cl1, and Cl3. Values indicate average diameter \pm SD $(\mu \mathrm{m})$. Scale bars: $10 \mu \mathrm{m}$. (C) Cell growth rate. The piPSCs proliferated more rapidly than established piPSC-ntESCs, where growth rates decreased across the $\mathrm{Cl} 2, \mathrm{Cl1}$, and $\mathrm{Cl} 3$ cell lines in association with increasing cell diameter. Each cell line (P15-20) was cultivated in a 35-mm dish at a seeding density of $8.0 \times 10^{5}$ at Day 0 (P0). The cells were passaged every two days at a ratio of 1:2 to 1:3 accordingly and maintained until Day 6 (P3). The data show the mean \pm SD of three replicates.

was not detected (Fig. 4A).

We next examined the expression of the six undifferentiated marker proteins OCT3/4, SOX2, KLF4, c-MYC, NANOG, and LIN28A. The expression of all proteins was positive after both western blotting (Fig. 4B) and immunofluorescent analyses (Fig. 4C). Although the antibodies used in this study cross-react with both mouse and pig epitopes, we confirmed that each protein was detected at the correct molecular weight and cellular localization. The expression of NANOG in $\mathrm{Cl1}$ probably reflects the endogenous porcine protein because mouse Nanog gene expression was not detected using RT-PCR (Fig. 
Table 1. Characterization established lines

\begin{tabular}{lcccccccccc}
\hline $\begin{array}{c}\text { Cell lines } \\
(\mathrm{P} 15-20)\end{array}$ & AP & $\begin{array}{c}\text { Cell size } \\
(\mu \mathrm{m})\end{array}$ & $\begin{array}{c}\text { Fluorescence } \\
(\text { ZsGreen })\end{array}$ & $\begin{array}{c}\text { Pluripotent } \\
\text { markers }\end{array}$ & $\begin{array}{c}\text { SSEA } \\
1 / 3 / 4\end{array}$ & COBRA & Teratoma & \multicolumn{2}{c}{ Chromosome number (\%) $^{\mathrm{c}}$} \\
\hline $\mathrm{Cl1}$ & + & $16.22 \pm 3.86$ & - & + & $+/+/+$ & $\mathrm{XaXi}$ & + & 9.0 & 88.0 & 38.0 \\
$\mathrm{Cl} 2$ & + & $12.61 \pm 1.51$ & + & + & $-/+/+$ & $\mathrm{XaXi}$ & + & 11.6 & 81.2 & 7.2 \\
$\mathrm{Cl3}$ & + & $20.39 \pm 3.99$ & + & + & $+/+/+$ & $\mathrm{XaXi}$ & + & 4.9 & 48.8 & 46.3 \\
piPSCs $^{\mathrm{a}}$ & + & $12.14 \pm 2.07$ & + & + & $-/+/+$ & $\mathrm{XaXa}$ & + & & ND \\
\hline
\end{tabular}

$\mathrm{AP}$, alkaline phosphatase; COBRA, combined bisulfite restriction analysis, $\mathrm{XaXi}$, one active and one inactive $\mathrm{X}$ chromosome; XaXa, two active X chromosomes. ${ }^{a}$ P42-46 was used. ${ }^{b}$ Diameter \pm SD. ${ }^{\mathrm{c}}$ About 50 mitotic spreads were examined. ND, not determined.

A

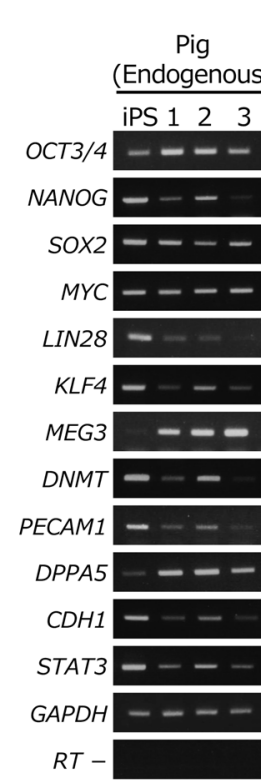

B

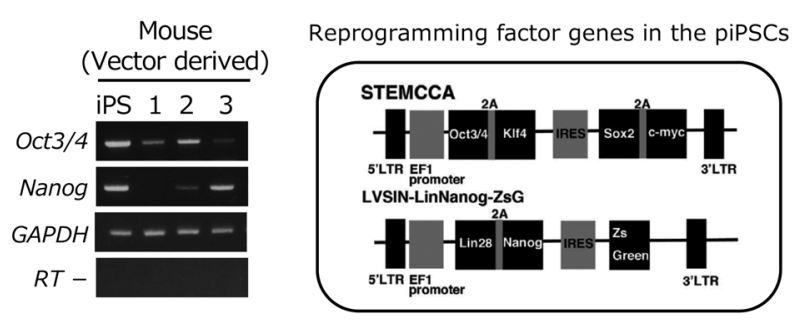

C

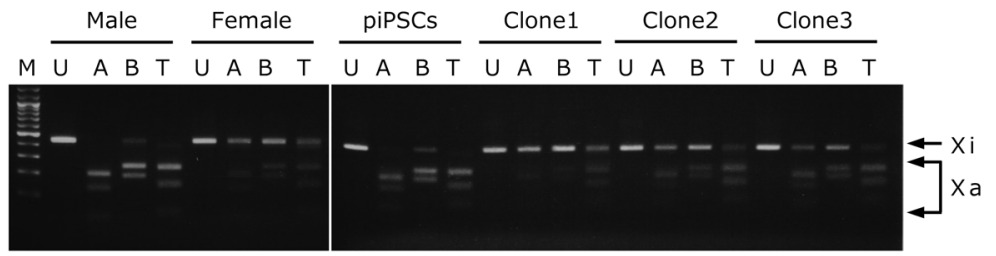

D

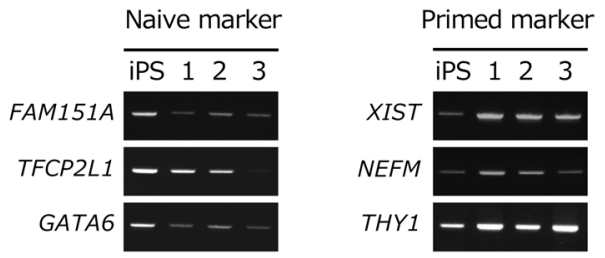

Fig. 3. The expression pattern of stem cell marker genes and combined bisulfite restriction analysis (COBRA). (A) Semi-quantitative reverse transcription (RT)-PCR for endogenous porcine transcripts. cDNA quantity in each sample was normalized to the level of GAPDH, and the PCR cycle number was set between 30-40. Most gene expression for Cl1-3 nuclear transfer-drived ESC (ntESC) was lower or equivalent compared to pluripotent stem cell (piPSC). The exceptions were OCT3/4, MEG3, and DPPA5, where expression levels were increased. As a negative control, RT- was performed using the GAPDH primer set for PCR. (B) The expression of mouse Oct3/4 and Nanog derived from the viral reprogramming vectors were suppressed in piPSC-ntESCs. Note that the mouse Nanog gene is located upstream of IRES-ZsGreen in the lentiviral vector (right panel) [12]. Nanog expression was not detected in the $\mathrm{Cl1}$ cells. This finding was consistent with the negative ZsGreen fluorescent signal in Cl1 (see Fig. 4A). RT- was performed using the mouse Oct3/4 primer set for PCR. (C) Methylation analysis of the XIST gene using COBRA. The activation status of the X chromosome in female piPSCs was confirmed as X chromosomes activated (XaXa). The three piPSC-ntESC lines were XaXi. Genomic DNA was subjected to bisulfite treatment, and the 441-bp PCR products were digested with AciI (A), BstUI (B), and TaqI (T) restriction enzymes. U: uncut control. M: 100 bp ladder marker. Genomic DNA extracted from male (XaY) and female (XaXi) embryonic fibroblasts was used as a reference. (D) The expression analysis of naïve and primed marker genes. Naïve marker genes, FAM151A, TFCP2L1, and GATA6 were more highly expressed in piPSCs than piPSC-ntESC lines. In contrast, the expression levels of the primed marker genes XIST, NEFM, and THY1 in Cl1-3 were higher than for piPSCs. The cDNA samples were the same as in (A).

3B) nor was ZsGreen (Fig. 4A). Therefore, LIN28A, which is also controlled under the same EF1 $\alpha$ promoter on the same lentiviral vector, also could reflect the endogenous protein. The transcription factor proteins OCT3/4, SOX2, KLF4, c-MYC, and NANOG were all detected in the nucleus, but LIN28A was more cytoplasmic (Fig.
4C). A similar staining and localization pattern was also observed in the $\mathrm{Cl} 2$ and $\mathrm{Cl} 3$ cells (data not shown).

\section{Teratoma formation}

The ability of ESCs to form teratomas is one of their defining 
A

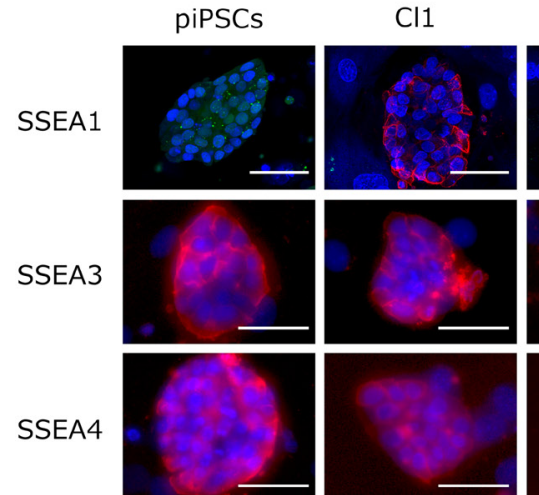

C

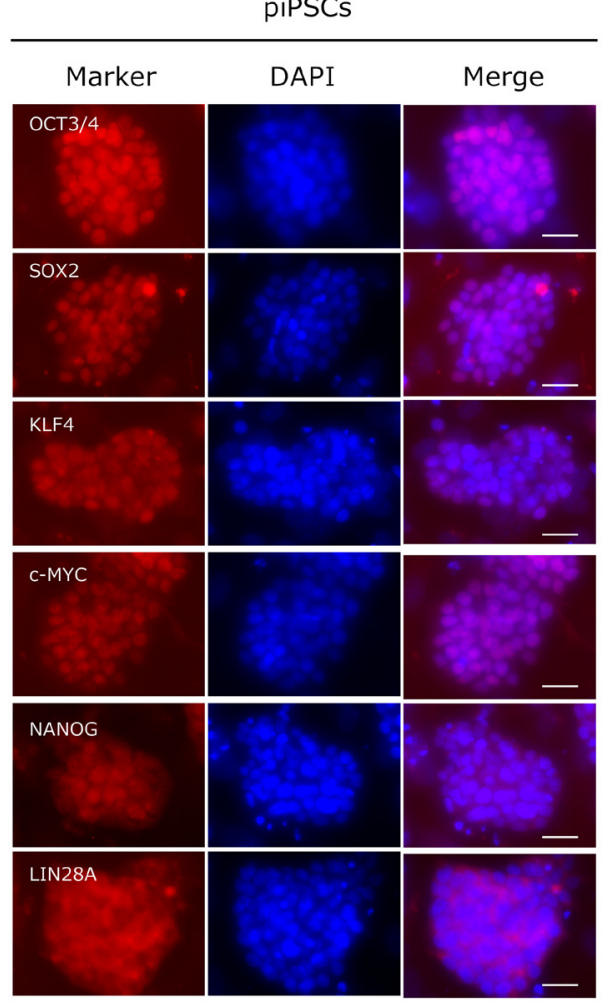

B

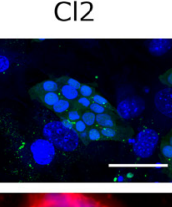

$\mathrm{Cl} 3$

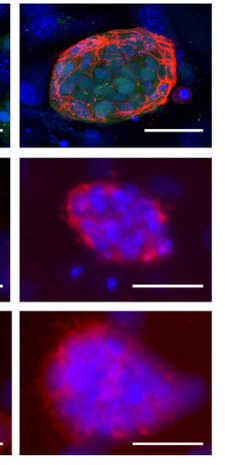

\begin{tabular}{ccc}
\multicolumn{3}{c}{ Cl1 } \\
\hline Marker & DAPI & Merge
\end{tabular}
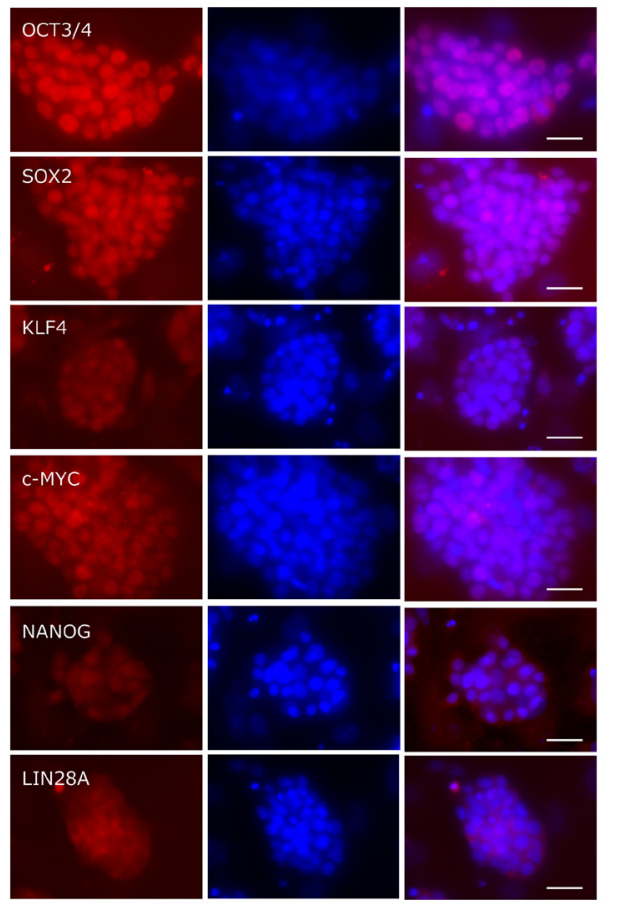

Fig. 4. Pluripotent stem cell marker protein expression. (A) Immunocytochemistry for SSEA1, SSEA3, and SSEA4. Merged representative images of SSEAs (red) with DAPI (blue) are shown. Confocal laser microscopy was used to detect SSEA1 and ZsGreen fluorescent signal. SSEA1 was positive in $\mathrm{Cl} 1$ and $\mathrm{Cl} 3$ but not in $\mathrm{Cl} 2$ nuclear transfer-drived ESCs (ntESCs) nor in the parental pluripotent stem cells (piPSCs). Note that ZsGreen was negative in the C11 cells. SSEA3 and SSEA4 were positive in all cell lines. Scale bars: $100 \mu \mathrm{m}$. (B) Detection of six pluripotent stem cell marker proteins using western blotting. All marker proteins were detected in the established clones. $\alpha$-tubulin control. (C) Immunocytochemistry for six pluripotent stem cell markers. OCT3/4, SOX2, KLF4, c-MYC, and NANOG proteins were detected in the nucleus, while LIN28A was cytoplasmic. Although only representative images for $\mathrm{Cl1}$ are shown, similar results were confirmed in $\mathrm{Cl} 2$ and $\mathrm{Cl} 3$. Scale bars: $50 \mu \mathrm{m}$.

characteristics. We tested the pluripotency of the established piPSCntESC lines in vivo using a teratoma formation assay. The injection of piPSC-ntESCs into the testes of SCID mice resulted in teratomas after 12 weeks in all mice. These contained solid tissues and fluid-filled cystic masses in each cell line (Fig. 5A). The macroscopic tumor size for each piPSC-ntESC line was proportional to the cell growth rate as shown in Fig. 2C. Teratomas contained derivatives of the three embryonic germ layers in all piPSC-ntESC lines. For example, ectodermal derivatives included neural tubes (Fig. 5B), pigmented cells (Fig. 5C) and squamous cells (Fig. 5E), endodermal derivatives 
included evidence of endodermal tubes (Fig. 5C) and intestinal formation (Fig. 5D), and mesodermal derivatives represented signs of angiogenesis (Fig. 5C), cartilage (Fig. 5E), smooth and striated muscle (Fig. 5F), and fat cells (Fig. 5G).

\section{SSEA expression in the nuclear transfer embryos}

We hypothesized that the SSEA expression pattern would differ between $8 \mathrm{C} / \mathrm{M}$ embryos and blastocysts since piPSC-ntESC lines were established from $8 \mathrm{C} / \mathrm{M}$ embryos but not blastocysts. We first compared the expression patterns of SSEA1, 3, and 4 between IVF and iPSC-nt embryos (Fig. 6A and B). Strong SSEA1 expression in IVF-derived embryos was observed at $8 \mathrm{C} / \mathrm{M}$ embryos, but only weak signals were evident at 4-cell and blastocyst stages. Weak SSEA4 expression was detected at the 4-cell, 8C/M, and blastocyst stages. However, SSEA3 was not detected at any pre-implantation stages examined in IVF embryos (Fig. 6A). Interesting results were obtained from iPSC-nt-derived embryos. Although SSEA1 expression was similar to IVF-derived embryos, SSEA3 was expressed at all stages examined, with noticeably strong expression observed in 4-cell and 8C/M stage embryos. Moreover, the SSEA4 expression level in $8 \mathrm{C} / \mathrm{M}$ embryos also appeared slightly stronger than IVF embryos at this stage (Fig. 6B). We next examined whether enhanced SSEA expression was restricted to iPSC-nt embryos. We examined embryos reconstructed using female PEFs (PEF-nt embryos) to compare. These PEFs were not from the cell line used to create the original piPSCs (from a 45-day embryo); they were from an unrelated fetus of the same approximate age (Day 50). PEF-nt oocytes were reconstructed in the same way as piPSC-nt oocytes, and the SSEA expression patterns were examined at each stage. The results were very similar to the iPSC-nt-derived embryos, showing strong SSEA1, 3 , and 4 expression in the $8 \mathrm{C} / \mathrm{M}$ embryos (Fig. $6 \mathrm{C}$ ) in contrast to IVF embryos, which were SSEA3 negative.

\section{Attempt to establish PEF-ntESC lines}

Finally, we tried to establish ESC lines from PEF-nt embryos using similar methods as piPSC-ntESCs. In total, 107 reconstructed $8 \mathrm{C} / \mathrm{M}$ embryos were produced from six replicates before transferring onto feeder cells. Nineteen (19/107, 17.8\%) began to outgrow, and eight $(8 / 107,7.5 \%)$ formed primary colonies (Fig. 6D). This proportion was the same as piPSC-nt embryos (Fig. 1D; 8/107, 7.5\% vs. 3/40, $7.5 \%$ ). However, none of the primary colonies derived from PEF-nt $8 \mathrm{C} / \mathrm{M}$ embryos developed further, and all degenerated after transfer to new feeder cells.

\section{Discussion}

Embryonic stem cells derived from cloned embryos (ntESCs) have been established in mouse [14], human [24-26], and cattle [27]. In addition, it has been reported that the success rate of cloning was higher when mouse ESCs were used as a source of donor cells compared to more differentiated somatic cells, which are more resistant to epigenetic reprogramming [13, 28-30]. The piPSCs used here were established using six murine reprogramming factors introduced into PEFs via lentiviral expression vectors. ZsGreen fluorescent reporter protein expression appears to link the undifferentiated state of piPSCs to depend on Lin28 and Nanog expression [12]. However, nt-embryos
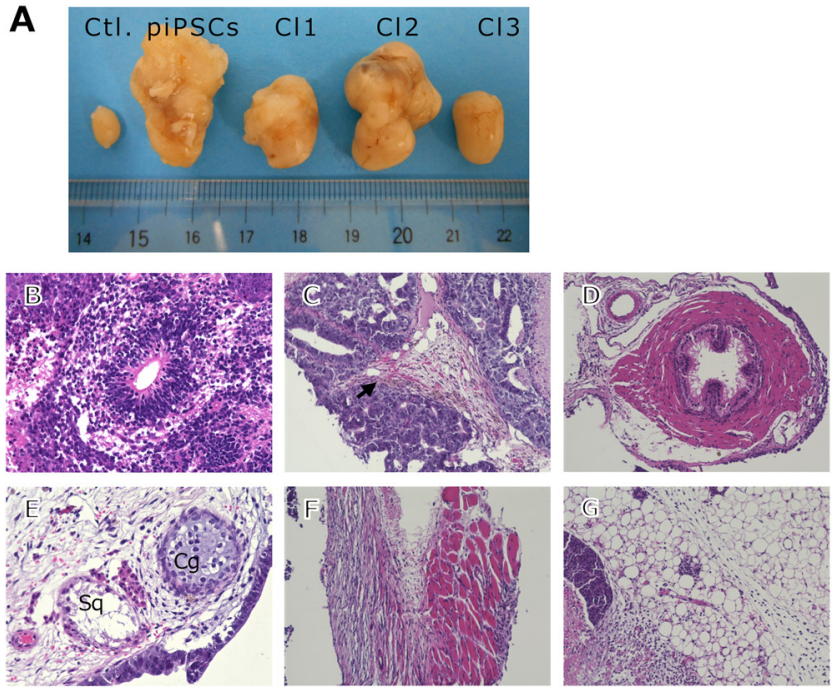

Fig. 5. Teratoma formation assay. (A) Gross tumor morphology. About 1 $\times 10^{6}$ cells were inoculated into SCID mouse testes, and teratoma formation was examined 12 weeks later. Tumor size was positively associated with the cell growth rate for each nuclear transferdrived ESC (ntESC) line (see Fig. 2C). (B) Neural tube surrounded by sheets of small neural precursor cells. (C) Several endodermal tubes and angiogenesis filled with blood is observed. Pigmented cells were also observed (arrow). (D) Intestine formation with a distinct eosinophilic smooth muscle layer. (E) Cartilage $(\mathrm{Cg})$ and squamous $(\mathrm{Sq})$ cells in loosely structured stroma. (F) Striated muscle bundle in the right side and smooth muscle in the center of the figure. (G) Adipose tissue composed of mature fat cells and fewer mature fat cells in the left lower portion of the figure. Magnification: (B and E) $400 \times$; C, D, F, and G) $200 \times$.

did not express ZsGreen until the late 4-cell stage, and not all embryos were fluorescence positive. This may have been due to various reprogramming effects. Even so, we initially hypothesized that the emission of the green fluorescent as a marker for the reprogramming factors in the reconstructed blastocysts would be restricted to the pluripotent ICM and to undifferentiated primary colonies, aiding selection and efficiency of ESC derivation.

One of the reasons for the developmental defects of nt-embryos is due to incorrect embryonic genome activation (EGA), which occurs at the 4-cell stage in pig [31, 32]. Here, the reconstructed embryos exhibited the green fluorescent protein from the late 4-cell stage onwards, suggesting that EGA occurred properly concomitant with the expression of vector-derived reprogramming factors. Although the reconstructed oocytes developed to apparently morphologically normal blastocysts, it is not yet known whether the embryos have competence for full-term development.

Contrary to our expectation, the green fluorescent protein following piPSC-nt was expressed in the entire blastocyst rather than just in the ICM. In other words, it was also in the trophoblast. Despite these observations, only fluorescence positive primary colonies arose from ICM during outgrowth culture, while the surrounding differentiated cells were negative. This could be due to ZsGreen fluorescent protein stability. Its detection in the trophoblast does not reflect active temporal or spatial expression at this stage. Ultimately, the growth of the 
A

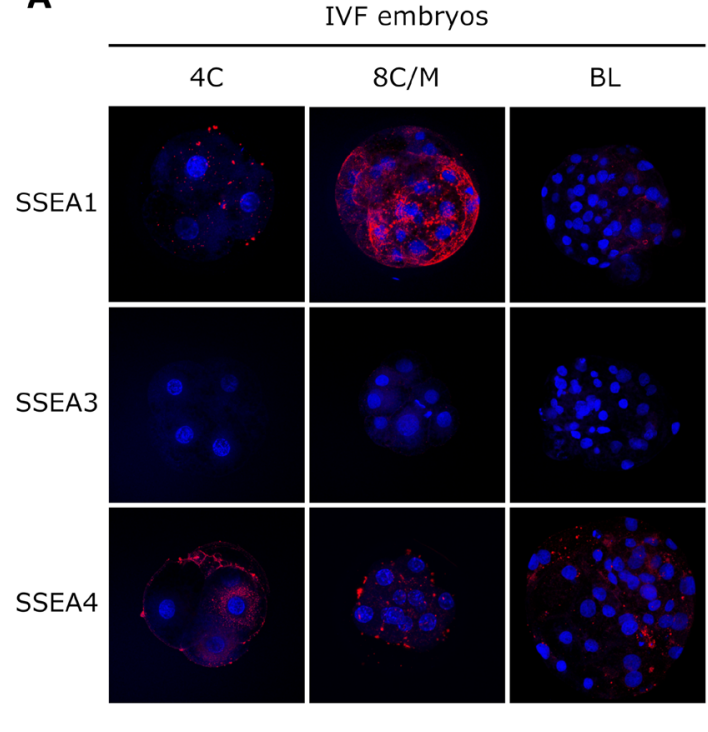

C

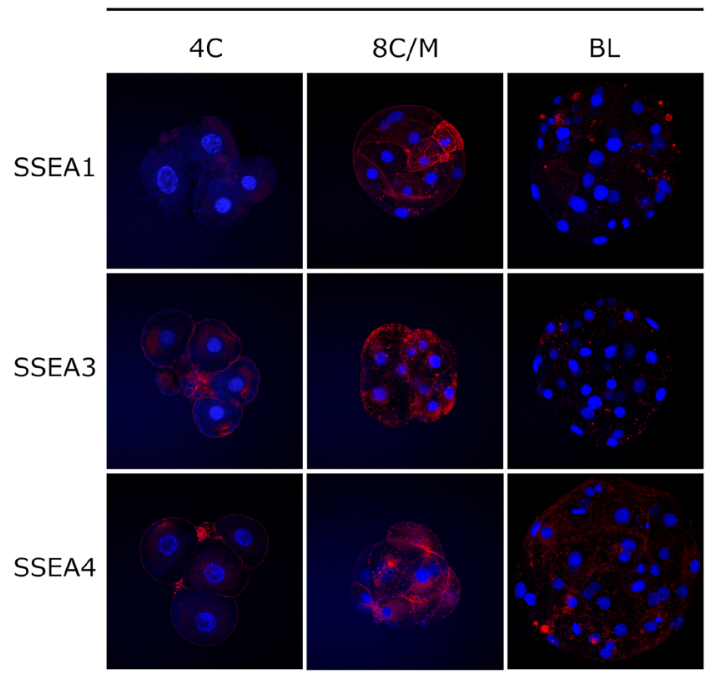

B iPSC-nt embryos

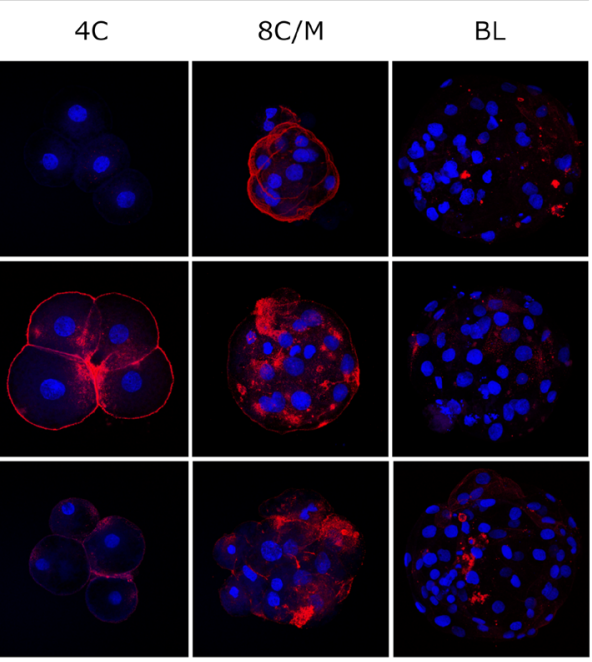

D

Out-growth and primary colonies from 8-cell/morula reconstructed with $\mathrm{PEF}$

\begin{tabular}{ccc}
\hline $\begin{array}{c}\text { No. of } \\
\text { 8-cell/morula }\end{array}$ & $\begin{array}{c}\text { Out-growth } \\
(\%)\end{array}$ & $\begin{array}{c}\text { Primary colony } \\
(\%)\end{array}$ \\
\hline 107 & $19(17.8 \%)$ & $8(7.5 \%)$ \\
\hline
\end{tabular}
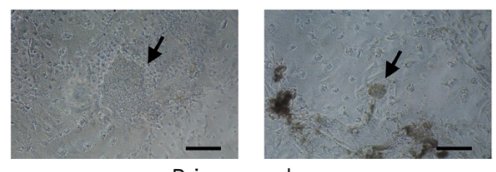

Primary colony

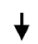

Degenerate

Fig. 6. SSEA1, 3, and 4 Expression in 4-cell, 8-cell/morula (8C/M), and blastocyst (BL) stage pig embryos derived from in vitro fertilization (IVF), iPSC-nt, and porcine embryonic fibroblast (PEF)-nt reconstructed oocytes. (A) IVF-derived embryos. SSEA1 was strongly expressed at the 8C/M embryos. Only faint signals for SSEA1 at BL and SSEA4 were observed at the 4-cell, 8C/M, and BL stages. However, SSEA3 signals were not detected at these pre-implantation stages. (B) pluripotent stem cells (piPSCs)-nt-derived embryos. A strong signal for SSEA1 was observed at the 8C/M embryos, just as for IVF-derived embryos. In contrast to IVF, strong SSEA3 expression was observed at the 4-cell and 8C/M stage embryos. Similarly, SSEA4 expression was enhanced at the $8 \mathrm{C} / \mathrm{M}$ embryos. (C) PEF-nt-derived embryos. SSEA expression pattern was similar to iPSC-nt-derived embryos. Taken together, SSEA1, 3, and 4 were all strongly expressed in nt-derived 8C/M embryos. (D) PEF-nt-derived 8C/M embryos were plated onto MEF feeders for outgrowth culture. Although typical primary colonies appeared (arrows), they degenerated soon after passage culture.

primary colonies derived from blastocysts could not be sustained, and they all degenerated. The derivation of piPSC-ntESCs from blastocysts could be successful if much larger numbers of blastocysts were cultured, but we decided instead to focus on earlier cleavage stages to establish piPSC-ntESCs, taking into consideration previous reports on mouse [33, 34] and human [35, 36] samples. Although the physical attachment of earlier stage embryos to the feeder cells is the first bottleneck, 2\% PVP supplementation in the ESC medium improved the proportion of $8 \mathrm{C} / \mathrm{M}$ embryos that attached to MEF feeder layer. Using $8 \mathrm{C} / \mathrm{M}$ embryos, we finally succeeded in establishing three relatively long-living piPSC-ntESC lines that showed several defining characteristics of primed pluripotent stem cells.

The established piPSC-ntESC lines display clonal variation, and they have the same genetic background (Table 1). Although there is a relationship in terms of the cell growth rate, cell diameter, and the gross tumor size between the three piPSC-ntESC lines, stem cell marker gene expression was more variable. The $\mathrm{Cl} 2$ line shows the fastest cell growth rate and tends to strongly express the endogenous 
undifferentiated marker genes. In Cl1 cells, vector-derived mouse Nanog and Zsgreen expression was not detected, suggesting integrated transgene silencing. It is possible that the pluripotent characteristics of the $\mathrm{Cl1}$ cells were in part maintained by this exogenous expression being replaced by endogenous porcine NANOG. This could also the case with LIN28A in the Cl1 cells, since its expression is also controlled by the same promotor in the lentiviral cassette. The C11, $\mathrm{Cl}$, and $\mathrm{Cl} 3$ lines all maintained their undifferentiated state and self-renewal capacity up to around 45 passages.

Our previously established pESLCs exhibit SSEA1 and SSEA4, but not SSEA3 expression [11]. Meanwhile, the piPSCs used as donor cells here are positive for SSEA3 and SSEA4, but not SSEA1. The $\mathrm{Cl} 2$ line appears to have inherited the parental piPSC characteristics, while the $\mathrm{Cl1}$ and $\mathrm{Cl} 3$ lines express all three SSEAs. Despite the parental piPSCs having both X chromosomes activated (XaXa), which we predict as an indicator for naïve pluripotency [37] in the pig, all three of the established female piPSC-ntESCs had inactivated one $\mathrm{X}$ chromosome and showed an $\mathrm{XaXi}$ status. This might suggest that the reprogramming process occurred properly in piPSC-nt embryo development, resulting in piPSC-ntESCs that more closely resembled primed pluripotent stem cells. While the presence of two active $\mathrm{X}$ chromosomes is a characteristic of naïve PSCs, previous studies have shown that even in primed human PSCs, defined by morphology, gene expression and signaling requirements, the activity state of the X chromosome is largely affected by prolonged culture [38] or feeder cells [39]. Here, characteristics of naïve piPSCs and primed piPSC-ntESCs were also demonstrated by the expression pattern of some naïve and primed marker genes. The marker genes examined here were previously used to characterize human ESCs [21, 22]. Although these marker genes have not been widely investigated, the results are informative and indicate the status of primed piPSC-ntESCs. Regardless of the clonal variation in some stem cell properties, the established piPSC-ntESC lines could all form teratomas in SCID mice. Kim et al. [40] reported putative porcine ESC lines derived from cloned blastocysts reconstructed with piPSCs. Those piPSCs were generated using plasmid vectors harboring four factors: Oct4, Klf4, Sox2, and $c M y c$ [41]. The primed state piPSCs that they described could not form teratomas. Furthermore, it is unclear whether the ESCs derived from their piPSC-nt can form teratomas. It has been reported that the anti-apoptotic gene survivin contributes to teratoma formation in human ESCs [42]. In addition, Fukuda et al. recently reported that higher expression of ERAS was observed in the piPSCs used here [43]. It would be informative to study ERAS's role in teratoma formation with the piPSC-ntESCs established here. Although chimera formation was not studied, the piPSC-ntESC lines display the hallmarks of both self-renewal and pluripotency.

It is noteworthy that the SSEAs expression pattern in nt-derived embryos differs compared to IVF-derived embryos. The strong expression of SSEA 3 and SSEA4 at the $8 \mathrm{C} / \mathrm{M}$ embryos emerged in reconstructed embryos derived from both iPSCs and PEFs. Although the appearance of primary colonies occurred in both cases, cell growth maintenance was achieved only with iPSC-nt-derived embryos initially expressing the six reprogramming factors. Despite weak SSEA expression in both IVF and nt-derived blastocysts, we previously established pESLCs from IVF blastocysts [11]. However, the results are not directly comparable because the medium used for each study differed. In addition, piPSC-ntESCs could be established from blastocysts with further effort and more embryos. In 8C/M pig embryos, strong SSEA expression might be necessary for the initial phase of stem cell colony formation, but the critical mechanisms underlying the difference in the isolation of pluripotent cells between $8 \mathrm{C} / \mathrm{M}$ embryos and blastocysts are not yet known. In a preliminary study, we found that putative porcine ESCs were efficiently obtained when the six porcine reprogramming factor genes (OCT3/4, NANOG, SOX2, c-MYC, LIN28, KLF4) were delivered as modified mRNAs [44] into outgrowth cells derived from porcine blastocysts (Haraguchi et al., unpublished data). However, the mRNAs must be continuously transfected into cells during outgrowth culture. Otherwise, the cells easily differentiate or degenerate. Taking this into account, continuous expression of reprogramming factors might be critical for establishment and maintenance of porcine pluripotent cells.

While this manuscript was being prepared, the establishment of porcine expanded potential stem cells (pEPSCs) was reported [8] using small molecule inhibitors for GSK3 (CHIR99021), SRC (WH-4-023), and Tankyrases (XAV939) [9], which were screened from over 400 combinations of 20 inhibitors tested. Since the piPSCs used here were created and maintained with the combined use of the small inhibitors CHIR99021, PD0325901, GFX109203, and thiazovivin [12], we used the same component medium here. In addition, pEPSC medium is supplemented with vitamin $\mathrm{C}$, Activin $\mathrm{A}$, and LIF. Likewise, the piPSC medium contains porcine LIF, which is necessary for passage culture of piPSCs [12]. Although the efficacy of Activin A was not examined, L-ascorbic acid was not used in the media here because previous studies had shown any that positive effect was equivocal in our culture system (Haraguchi et al., unpublished). Nevertheless, the establishment of pEPSCs by Gao et al. is a landmark in terms of defining a novel stem cell type with extended developmental potential without the need of integrating reprogramming vectors.

In summary, we successfully established piPSC-ntESC lines that possess some characteristics of primed pluripotent stem cells. We observed that embryos reconstructed using nuclear transfer cloning strongly express SSEA1, SSEA3, and SSEA4 in 8C/M embryos. This is unlike IVF embryos. The biological significance of the cell surface antigens in cloned embryos at this stage is unclear. The early sustained expression of the six core reprogramming transcription factors is thought to be key for the establishment of pluripotent piPSC-ntESC lines.

\section{Acknowledgements}

The authors would like to thank to the members of Transgenic Animal Research Laboratory. This work was supported by NARO fund, CJN13HW0.

\section{References}

1. Buehr M, Meek S, Blair K, Yang J, Ure J, Silva J, McLay R, Hall J, Ying QL, Smith A. Capture of authentic embryonic stem cells from rat blastocysts. Cell 2008; 135: 1287-1298. [Medline] [CrossRef]

2. Li P, Tong C, Mehrian-Shai R, Jia L, Wu N, Yan Y, Maxson RE, Schulze EN, Song H, Hsieh CL, Pera MF, Ying QL. Germline competent embryonic stem cells derived from rat blastocysts. Cell 2008; 135: 1299-1310. [Medline] [CrossRef]

3. Evans MJ, Kaufman MH. Establishment in culture of pluripotential cells from mouse 
embryos. Nature 1981; 292: 154-156. [Medline] [CrossRef]

4. Martin GR. Isolation of a pluripotent cell line from early mouse embryos cultured in medium conditioned by teratocarcinoma stem cells. Proc Natl Acad Sci USA 1981; 78: 7634-7638. [Medline] [CrossRef]

5. Nichols J, Smith A. Naive and primed pluripotent states. Cell Stem Cell 2009; 4: 487-492. [Medline] [CrossRef]

6. Tesar PJ, Chenoweth JG, Brook FA, Davies TJ, Evans EP, Mack DL, Gardner RL, McKay RD. New cell lines from mouse epiblast share defining features with human embryonic stem cells. Nature 2007; 448: 196-199. [Medline] [CrossRef]

7. Brons IG, Smithers LE, Trotter MW, Rugg-Gunn P, Sun B, Chuva de Sousa Lopes SM, Howlett SK, Clarkson A, Ahrlund-Richter L, Pedersen RA, Vallier L. Derivation of pluripotent epiblast stem cells from mammalian embryos. Nature 2007; 448: 191-195. [Medline] [CrossRef]

8. Gao X, Nowak-Imialek M, Chen X, Chen D, Herrmann D, Ruan D, Chen ACH, Eckersley-Maslin MA, Ahmad S, Lee YL, Kobayashi T, Ryan D, Zhong J, Zhu J, Wu J, Lan G, Petkov S, Yang J, Antunes L, Campos LS, Fu B, Wang S, Yong Y, Wang X, Xue SG, Ge L, Liu Z, Huang Y, Nie T, Li P, Wu D, Pei D, Zhang Y, Lu L, Yang F, Kimber SJ, Reik W, Zou X, Shang Z, Lai L, Surani A, Tam PPL, Ahmed A, Yeung WSB, Teichmann SA, Niemann H, Liu P. Establishment of porcine and human expanded potential stem cells. Nat Cell Biol 2019; 21: 687-699. [Medline] [CrossRef]

9. Yang J, Ryan DJ, Wang W, Tsang JC, Lan G, Masaki H, Gao X, Antunes L, Yu Y, Zhu Z, Wang J, Kolodziejczyk AA, Campos LS, Wang C, Yang F, Zhong Z, Fu B, Eckersley-Maslin MA, Woods M, Tanaka Y, Chen X, Wilkinson AC, Bussell J, White J, Ramirez-Solis R, Reik W, Göttgens B, Teichmann SA, Tam PPL, Nakauchi H, Zou X, Lu L, Liu P. Establishment of mouse expanded potential stem cells. Nature 2017; 550: 393-397. [Medline] [CrossRef]

10. Niu D, Wei HJ, Lin L, George H, Wang T, Lee IH, Zhao HY, Wang Y, Kan Y, Shrock E, Lesha E, Wang G, Luo Y, Qing Y, Jiao D, Zhao H, Zhou X, Wang S, Wei H, Güell M, Church GM, Yang L. Inactivation of porcine endogenous retrovirus in pigs using CRISPR-Cas9. Science 2017; 357: 1303-1307. [Medline] [CrossRef]

11. Haraguchi S, Kikuchi K, Nakai M, Tokunaga T. Establishment of self-renewing porcine embryonic stem cell-like cells by signal inhibition. J Reprod Dev 2012; 58: 707-716. [Medline] [CrossRef]

12. Fukuda T, Tani T, Haraguchi S, Donai K, Nakajima N, Uenishi H, Eitsuka T, Miyagawa M, Song S, Onuma M, Hoshino Y, Sato E, Honda A. Expression of six proteins causes reprogramming of porcine fibroblasts into induced pluripotent stem cells with both active X chromosomes. $J$ Cell Biochem 2017; 118: 537-553. [Medline] [CrossRef]

13. Rideout WM 3rd, Wakayama T, Wutz A, Eggan K, Jackson-Grusby L, Dausman J, Yanagimachi R, Jaenisch R. Generation of mice from wild-type and targeted ES cells by nuclear cloning. Nat Genet 2000; 24: 109-110. [Medline] [CrossRef]

14. Wakayama T, Tabar V, Rodriguez I, Perry AC, Studer L, Mombaerts P. Differentiation of embryonic stem cell lines generated from adult somatic cells by nuclear transfer. Science 2001; 292: 740-743. [Medline] [CrossRef]

15. Dang-Nguyen TQ, Nguyen HT, Somfai T, Wells D, Men NT, Viet-Linh N, Noguchi J, Kaneko H, Kikuchi K, Nagai T. Sucrose assists selection of high-quality oocytes in pigs. Anim Sci J 2018; 89: 880-887. [Medline] [CrossRef]

16. Oback B, Wells DN. Cloning cattle. Cloning Stem Cells 2003; 5: 243-256. [Medline] [CrossRef]

17. Akagi S, Kaneyama K, Adachi N, Tsuneishi B, Matsukawa K, Watanabe S, Kubo M, Takahashi S. Bovine nuclear transfer using fresh cumulus cell nuclei and in vivo- or in vitro-matured cytoplasts. Cloning Stem Cells 2008; 10: 173-180. [Medline] [CrossRef]

18. Kikuchi K, Onishi A, Kashiwazaki N, Iwamoto M, Noguchi J, Kaneko H, Akita T, Nagai T. Successful piglet production after transfer of blastocysts produced by a modified in vitro system. Biol Reprod 2002; 66: 1033-1041. [Medline] [CrossRef]

19. Suzuki K, Asano A, Eriksson B, Niwa K, Nagai T, Rodriguez-Martinez H. Capacitation status and in vitro fertility of boar spermatozoa: effects of seminal plasma, cumulusoocyte-complexes-conditioned medium and hyaluronan. Int J Androl 2002; 25: 84-93. [Medline] [CrossRef]

20. Dang-Nguyen TQ, Haraguchi S, Kikuchi K, Somfai T, Bodó S, Nagai T. Leukemia inhibitory factor promotes porcine oocyte maturation and is accompanied by activation of signal transducer and activator of transcription 3. Mol Reprod Dev 2014; 81: 230-239. [Medline] [CrossRef]

21. Messmer T, von Meyenn F, Savino A, Santos F, Mohammed H, Lun ATL, Marioni JC, Reik W. Transcriptional heterogeneity in naive and primed human pluripotent stem cells at single-cell resolution. Cell Reports 2019; 26: 815-824.e4. [Medline] [CrossRef]

22. Sahakyan A, Kim R, Chronis C, Sabri S, Bonora G, Theunissen TW, Kuoy E, Langerman J, Clark AT, Jaenisch R, Plath K. Human naive pluripotent stem cells model X chromosome dampening and X inactivation. Cell Stem Cell 2017; 20: 87-101. [Medline] [CrossRef]

23. Damjanov I, Andrews PW. Teratomas produced from human pluripotent stem cells xenografted into immunodeficient mice - a histopathology atlas. Int J Dev Biol 2016; 60: 337-419. [Medline] [CrossRef]
24. Tachibana M, Amato P, Sparman M, Gutierrez NM, Tippner-Hedges R, Ma H, Kang E, Fulati A, Lee HS, Sritanaudomchai H, Masterson K, Larson J, Eaton D, SadlerFredd K, Battaglia D, Lee D, Wu D, Jensen J, Patton P, Gokhale S, Stouffer RL, Wolf D, Mitalipov S. Human embryonic stem cells derived by somatic cell nuclear transfer. Cell 2013; 153: 1228-1238. [Medline] [CrossRef]

25. Chung YG, Eum JH, Lee JE, Shim SH, Sepilian V, Hong SW, Lee Y, Treff NR, Choi YH, Kimbrel EA, Dittman RE, Lanza R, Lee DR. Human somatic cell nuclear transfer using adult cells. Cell Stem Cell 2014; 14: 777-780. [Medline] [CrossRef]

26. Yamada M, Johannesson B, Sagi I, Burnett LC, Kort DH, Prosser RW, Paull D, Nestor MW, Freeby M, Greenberg E, Goland RS, Leibel RL, Solomon SL, Benvenisty N, Sauer MV, Egli D. Human oocytes reprogram adult somatic nuclei of a type 1 diabetic to diploid pluripotent stem cells. Nature 2014; 510: 533-536. [Medline] [CrossRef]

27. Furusawa T, Ohkoshi K, Kimura K, Matsuyama S, Akagi S, Kaneda M, Ikeda M, Hosoe M, Kizaki K, Tokunaga T. Characteristics of bovine inner cell mass-derived cell lines and their fate in chimeric conceptuses. Biol Reprod 2013; 89: 28. [Medline] [CrossRef]

28. Wakayama S, Mizutani E, Kishigami S, Thuan NV, Ohta H, Hikichi T, Bui HT, Miyake M, Wakayama T. Mice cloned by nuclear transfer from somatic and ntES cells derived from the same individuals. J Reprod Dev 2005; 51: 765-772. [Medline] [CrossRef]

29. Wakayama S, Wakayama T. Improvement of mouse cloning using nuclear transferderived embryonic stem cells and/or histone deacetylase inhibitor. Int J Dev Biol 2010; 54: 1641-1648. [Medline] [CrossRef]

30. Wakayama T, Rodriguez I, Perry AC, Yanagimachi R, Mombaerts P. Mice cloned from embryonic stem cells. Proc Natl Acad Sci USA 1999; 96: 14984-14989. [Medline] [CrossRef]

31. Jarrell VL, Day BN, Prather RS. The transition from maternal to zygotic control of development occurs during the 4-cell stage in the domestic pig, Sus scrofa: quantitative and qualitative aspects of protein synthesis. Biol Reprod 1991; 44: 62-68. [Medline] [CrossRef]

32. Cao S, Han J, Wu J, Li Q, Liu S, Zhang W, Pei Y, Ruan X, Liu Z, Wang X, Lim B, Li N. Specific gene-regulation networks during the pre-implantation development of the pig embryo as revealed by deep sequencing. BMC Genomics 2014; 15: 4. [Medline] [CrossRef]

33. Wakayama S, Hikichi T, Suetsugu R, Sakaide Y, Bui HT, Mizutani E, Wakayama T Efficient establishment of mouse embryonic stem cell lines from single blastomeres and polar bodies. Stem Cells 2007; 25: 986-993. [Medline] [CrossRef]

34. Bag S, Pfannkuche K, Krzyzak V, Wagner B, Sachinidis A, Hescheler J. Derivation of es cells from early stage preimplantation embryos and characterisation of their cardiac differentiation potential in mice. J Stem Cells Regen Med 2012; 8: 12-20. [Medline]

35. Geens M, Mateizel I, Sermon K, De Rycke M, Spits C, Cauffman G, Devroey P, Tournaye H, Liebaers I, Van de Velde H. Human embryonic stem cell lines derived from single blastomeres of two 4-cell stage embryos. Hum Reprod 2009; 24: 2709-2717. [Medline] [CrossRef]

36. Klimanskaya I, Chung Y, Becker S, Lu SJ, Lanza R. Human embryonic stem cell lines derived from single blastomeres. Nature 2006; 444: 481-485. [Medline] [CrossRef]

37. Hanna J, Cheng AW, Saha K, Kim J, Lengner CJ, Soldner F, Cassady JP, Muffat J, Carey BW, Jaenisch R. Human embryonic stem cells with biological and epigenetic characteristics similar to those of mouse ESCs. Proc Natl Acad Sci USA 2010; 107: 9222-9227. [Medline] [CrossRef]

38. Mekhoubad S, Bock C, de Boer AS, Kiskinis E, Meissner A, Eggan K. Erosion of dosage compensation impacts human iPSC disease modeling. Cell Stem Cell 2012; 10: 595-609. [Medline] [CrossRef]

39. Tomoda K, Takahashi K, Leung K, Okada A, Narita M, Yamada NA, Eilertson KE, Tsang P, Baba S, White MP, Sami S, Srivastava D, Conklin BR, Panning B, Yamanaka S. Derivation conditions impact X-inactivation status in female human induced pluripotent stem cells. Cell Stem Cell 2012; 11: 91-99. [Medline] [CrossRef]

40. Kim E, Hwang SU, Yoo H, Yoon JD, Jeon Y, Kim H, Jeung EB, Lee CK, Hyun SH. Putative embryonic stem cells derived from porcine cloned blastocysts using induced pluripotent stem cells as donors. Theriogenology 2016; 85: 601-616. [Medline] [CrossRef]

41. Park JK, Kim HS, Uh KJ, Choi KH, Kim HM, Lee T, Yang BC, Kim HJ, Ka HH, Kim H, Lee CK. Primed pluripotent cell lines derived from various embryonic origins and somatic cells in pig. PLoS One 2013; 8: e52481. [Medline] [CrossRef]

42. Blum B, Bar-Nur O, Golan-Lev T, Benvenisty N. The anti-apoptotic gene survivin contributes to teratoma formation by human embryonic stem cells. Nat Biotechnol 2009; 27: 281-287. [Medline] [CrossRef]

43. Fukuda T, Doi K, Donai K, Takahashi K, Kobayashi H, Hirano T, Nishimori K, Yasue H. Global transcriptome analysis of pig induced pluripotent stem cells derived from six and four reprogramming factors. Sci Data 2019; 6: 190034. [Medline] [CrossRef]

44. Warren L, Manos PD, Ahfeldt T, Loh YH, Li H, Lau F, Ebina W, Mandal PK, Smith ZD, Meissner A, Daley GQ, Brack AS, Collins JJ, Cowan C, Schlaeger TM, Rossi DJ. Highly efficient reprogramming to pluripotency and directed differentiation of human cells with synthetic modified mRNA. Cell Stem Cell 2010; 7: 618-630. [Medline] [CrossRef] 